ks. Marek Kluz

\title{
Posłannictwo osób konsekrowanych we współczesnym świecie
}

Dzień Życia Konsekrowanego, obchodzony w każde święto Ofiarowania Pańskiego, w dniu 2 lutego 2015 roku miał charakter szczególny. Wpisał się bowiem w ogłoszony przez ojca świętego Franciszka Rok Życia Konsekrowanego, przeżywany pod hasłem: „Ewangelia, proroctwo, nadzieja - życie konsekrowane w Kościele dzisiaj”. Rok ten rozpoczął się w pierwszą niedzielę Adwentu 2014 roku, a zakończył 2 lutego 2016 roku.

Już na samym początku trzeba wyraźnie podkreślić, że z misją i świętością Kościoła w świecie w szczególny sposób zespolone jest życie konsekrowane, albowiem wyraża ono samą istotę powołania chrześcijańskiego. Kodeks prawa kanonicznego w następujący sposób definiuje ten stan życia:

Życie konsekrowane przez profesję rad ewangelicznych jest trwałą formą życia, w której wierni pod działaniem Ducha Świętego naśladując dokładniej Chrystusa, oddają się całkowicie umiłowanemu nade wszystko Bogu, ażeby - poświęceni z nowego i szczególnego tytułu dla chwały Boga, budowania Kościoła i zbawienia świata - osiągnąć doskonałą miłość w służbie Królestwa Bożego i, stawszy się w Kościele wyraźnym znakiem, zapowiadać niebieską chwałę ${ }^{1}$. 
W czasach duchowego zagubienia i zamętu, gdy szerzą się tendencje liberalne i laickie, sekularyzm i relatywizm moralny, potrzebne jest Kościołowi i światu zdecydowane świadectwo. Moc świadectwa wpisana jest w powołanie każdego chrześcijanina, ale szczególnie w powołanie osób konsekrowanych ${ }^{2}$. Dlatego słuszne jest wołanie papieża Benedykta XVI:

Kościół potrzebuje waszego świadectwa, potrzebuje życia konsekrowanego, które z odwagą i w sposób twórczy podejmuje wyzwania naszych czasów. Wobec szerzenia się hedonizmu od was oczekuje się odważnego świadectwa czystości, będącej wyrazem serca znającego piękno i cenę Bożej miłości. Wobec dominującego dziś powszechnie pragnienia pieniądza waszym skromnym życiem i gotowością służenia najbardziej potrzebującym przypominacie, że Bóg jest prawdziwym bogactwem, które nie niszczeje. Wobec indywidualizmu i relatywizmu, prowadzących do tego, że człowiek staje się dla siebie jedyną normą, wasze braterskie życie zdolne poddać się kierownictwu, a więc gotowość do posłuszeństwa, potwierdza, że realizację samych siebie składacie w ręce Boga. Jakże nie wyrazić życzenia, żeby kultura rad ewangelicznych, będąca kulturą Blogosławieństw, mogła szerzyć się w Kościele, by podtrzymywać życie i świadectwo ludu chrześcijańskiego?3?.

Odnowa Kościoła i świata wiąże się więc ściśle i nierozerwalnie z powołaniem osób konsekrowanych, które mają w tym względzie niezwykle ważną rolę do spełnienia. Szczególne miejsce, jakie osoby konsekrowane zajmują we wspólnocie Kościoła, zobowiązuje je do podjęcia odpowiedzialności za misję Chrystusa w świecie.

\section{Troska o ewangelizację misyjną}

Obowiązek głoszenia słowa Bożego spoczywa na każdym uczniu Jezusa Chrystusa. Każdy ochrzczony powinien czuć się odpowiedzialny za Kościół, który jest z natury misyjny ${ }^{4}$. Osoby konsekrowane,

2 Por. Benedykt XVI, Adh. apost. Verbum Domini, nr 83. Por. także: B. Rozen, Świętość w życiu konsekrowanym, „Ateneum Kapłańskie” t. 145 (2005) nr 578, s. 130-134.

3 Benedykt XVI, „Kościót i świat potrzebują waszego świadectwa”. Przemówienie do osób konsekrowanych diecezji rzymskiej (Watykan, 10.12.2005).

4 Por. Sobór Watykański II, Dekret o działalności misyjnej Kościoła Ad gentes divinitus, $\mathrm{nr} 2$. 
zwane również pielgrzymami, naznaczone są szczególnym powołaniem misyjnym. Jan Paweł II w adhortacji apostolskiej Vita consecrata podkreśla to wyraźnie:

Życie konsekrowane, głęboko zakorzenione w przykładzie życia i nauczaniu Chrystusa Pana, jest darem Boga Ojca udzielonym Jego Kościołowi za sprawą Ducha Świętego. Dzięki profesji rad ewangelicznych charakterystyczne przymioty Jezusa - dziewictwo, ubóstwo i posłuszeństwo - stają się w pewien swoisty i trwały sposób „,widzialne” w świecie, a spojrzenie wiernych zwraca się ku tajemnicy Królestwa Bożego, które już jest obecne w historii, ale w pełni urzeczywistni się w niebie. W ciągu stuleci nigdy nie zabrakło ludzi, którzy - idąc posłusznie za wezwaniem Ojca i poruszeniami Ducha Świętego - wybrali tę drogę specjalnego naśladowania Chrystusa, aby oddać się Jemu sercem ,niepodzielnym” (por. 1 Kor 7, 34). Oni także porzucili wszystko jak Apostołowie, aby przebywać z Nim i tak jak On oddać się na służbę Bogu i braciom. W ten sposób przyczynili się do objawienia tajemnicy i misji Kościoła dzięki licznym charyzmatom życia duchowego i apostolskiego, których udzielał im Duch Święty, a w ten sposób wnieśli też wkład w odnowę społeczeństwa5

Z papieskich słów wynika więc jasno, że życie konsekrowane jest ważną sprawą całego Kościoła. Znajduje się ono w sercu Kościoła jako znaczący element jego misji, ponieważ wyraża najgłębszą istotę chrześcijańskiego powołania. Stanowi ono cenny dar dla Ludu Bożego $^{6}$. Życie konsekrowane jest świadectwem tego, że im bardziej żyje się Chrystusem, tym ofiarniej można służyć Mu w bliźnich, bowiem ten, kto miłuje Boga, wszystkich powinien miłować?

Praca misyjna osób poświęconych Bogu powinna być konfrontowana z ewangelicznym oraz wspólnotowym projektem życia, ponieważ wszelkie poczynania związane z doczesną misją Kościoła nie mają znaczenia bez doczesnego zjednoczenia z Ojcem i Synem i Duchem Świętym. Misja prowadzona w imię Boże oraz zjednoczenie z Bogiem są wyrazem widzialnego sakramentu Bożej wspólnoty na ziemi

Jan Paweł II, Adh. apost. Vita consecrata, nr 1 [dalej: VC].

Por. VC 3.

Por. VC 77.

2148 Por. G. Bini, Zakon dzisiaj-refleksje i perspektywy, Rzym 2000, s. 36. 
Tak więc osoby konsekrowane z racji szczególnego zawierzenia i oddania się Bogu na Jego chwałę są szczególnie zobowiązane do realizacji misyjnego mandatu Jezusa Chrystusa. Osoby konsekrowane poprzez profesję rad ewangelicznych stają się bardziej podobne do Tego, który je powołał i posłał. Osoby te wchodzą w życiowe i dynamiczne spotkanie z Jezusem, co bardzo wplywa na ich zaangażowanie i pomaga na drodze misyjnej, gdyż napełnione Chrystusem, promieniują Nim na ludzi, których Chrystus stawia im na ich drodze. Naśladowanie Chrystusa przez osoby poświęcone Bogu powoduje, iż dane osoby stają się ikoną ziemskiego życia Chrystusa. Ponadto życie radami ewangelicznymi, w czystości, posłuszeństwie i ubóstwie, czyni dane osoby wolnymi i dyspozycyjnymi do wszelkich zadań misji, jakich zażąda Chrystus w Kościele. Tak pojęta misja jest niewątpliwie wyrazem miłości Boga i człowieka9.

II Sobór Watykański, dziękując za wielki wkład misyjny instytutom doskonałości chrześcijańskiej, zarówno kontemplacyjnym, jak i czynnym, zachęca, aby nadal rozwijały to Boże dzieło, jakim są misje. Tenże Sobór zaleca, aby instytuty zakonne pracujące na misjach na początku stopniowo dzieliły się swoimi przeżyciami mistycznymi i przekazywały prawdy objawione narodom, do których zostały posłane. Ponadto ojcowie soborowi zalecają, aby w nowo założonych Kościołach pielęgnować i rozwijać różne formy życia zakonnego. Ma to na celu ukazanie różnych rodzajów misji Chrystusowej, a także misji życia Kościoła ${ }^{10}$.

Osoby konsekrowane winny do głębi przejąć się problemami i potrzebami całego świata. Powinny również otoczyć je modlitwą i działaniem. Zaangażowanie to ma plynąć z wezwania Ducha Świętego, który kieruje swoim Kościołem ${ }^{11}$.

W ten sposób życie konsekrowane nie będzie się ograniczać do samego odczytywania znaków czasu, ale przyczyni się także do wypracowania nowych programów ewangelizacji dostosowanych do potrzeb dnia dzisiejszego; wszystko to w przeświadczeniu płynącym z wiary, że Duch Święty potrafi udzielić właściwych odpowiedzi nawet na najtrudniejsze pytania. Warto przypomnieć to, czego nauczali

9 Por. A. Warot, Servitium caritatis, w: Dalsza refleksja nad życiem konsekrowanym, red. K. Wójtowicz, Kraków 2000, s. 117-118.

10 Por. szerzej: Jan Paweł II, Enc. Redemptoris missio (7.12.1990) [dalej: RM], nr 65-70.

11 Por. szerzej: RM 21-29. 
zawsze wielcy protagoniści działalności apostolskiej: trzeba ufać Bogu tak, jakby wszystko zależało tylko od Niego, ale i pracować niestrudzenie, jakby wszystko zależało tylko od nas ${ }^{12}$.

Wszelka działalność osób konsekrowanych powinna być czyniona $\mathrm{w}$ dialogu z innymi podmiotami Kościoła. Wyzwania misyjne są na tyle duże, że nie mogą być podejmowane bez pełnej współpracy wszystkich członków Kościoła. Chodzi tu zarówno o sferę rozeznania, jak i działania, które jest owocem dialogu ${ }^{13}$. Zwłaszcza współdziałanie między zgromadzeniami o różnych charyzmatach może przyczynić się do wzajemnego wzbogacenia i większej skuteczności w misji ewangelizacyjnej. Dialog bowiem jest nowym imieniem miłości. Pozwala zobaczyć problemy w ich prawdziwych proporcjach i podejmować się ich rozwiązania zjak największą nadzieją na powodzenie ${ }^{14}$. Współpraca taka pozwala na podział obowiązków zależnie od możliwości, co sprzyja skutecznemu docieraniu do rozwiązywania wspólnych przecież problemów. Gdyż nic, co dzieje się w Kościele - wspólnocie, nie jest sprawą jednego zgromadzenia.

Osoba konsekrowana pełni misję, dając świadectwo samą swą osobą i swą konsekracją. Poprzez działanie zgodne z programem swojego instytutu daje świadectwo życia, a także wypełnia dzieła apostolskie służące ludziom. Jest to więc działalność dla chwały Boga, jak również ku zbawieniu ludzi. Chrześcijanie oddani Bogu przez życie zakonne mają do spełnienia szczególne zadanie w misyjnym dziele Kościoła ${ }^{15}$. O tym należy zawsze pamiętać, gdyż odnosi się to do zamysłu Bożego wobec ludzi.

\section{Troska o jedność uczniów Chrystusa}

Wspólnota zakonna jest wyjątkowym znakiem nadprzyrodzonej jedności w Jezusie Chrystusie. Osoby konsekrowane, będące częścią tej wspólnoty, już poprzez to stają się wymownym znakiem tej jedności. Stan zakonny, wrośnięty w Kościół, przyjmuje funkcję znaku jedności w Kościele i jest powołaniem do budowania tej jedności

\footnotetext{
VC 73.

Por. Franciszek, Adh. apost. Evangelii gaudium (24.11.2013) [dalej: EG], nr 20.

Por. VC 74.

15 Por. R. M. René, Wspótpracownicy w ewangelizacji, w: Elementy teologii misyjnej, brak red., Pieniężno 1987, s. 16.
} 
poprzez angażowanie się w tajemnicę odkupienia. Osoby konsekrowane doświadczające komunii we wspólnocie zakonnej zobowiązane są do tego, aby być przykładem dla tych, którzy świadczą o Ewangelii każdego dnia. Świadectwo to jest bardzo pomocne w przezwyciężaniu różnych trudności, związanych z głoszeniem Chrystusa, szczególnie dla osób świeckich ${ }^{16}$.

Doskonała komunia w Kościele wedle zamysłu Bożego jest szczytem historii człowieka. Przez profesję rad ewangelicznych, które uwalniają miłość od wszelkich ograniczeń i czynią osobę konsekrowaną dyspozycyjną wobec Boga, zakonnicy stają się znakiem miłości i jedności z Bogiem. Ponadto osoby te bardziej wyrażają znak wspólnoty braterskiej poprzez wspólne życie, modlitwę i apostolstwo.

Osoby konsekrowane, żyjące we wspólnotach braterskich, powołane są zatem, aby być twórcami i świadkami komunii w Kościele. W świecie tak często głęboko podzielonym z różnego rodzaju przyczyn, podzielonym także w wierze, zakonnicy dają świadectwo, iż wspólna praca, modlitwa, sposób życia są możliwe. Jest to również świadectwo przyjęcia zaproszenia Chrystusa oraz wierniejszego naśladowania Go, a także świadectwo wspólnoty braterskiej, które Jezus Chrystus ustanowił za pośrednictwem Ducha Świętego ${ }^{17}$.

Trzeba też w tym miejscu podkreślić, że dla dobra jedności chrześcijan i komunii w Kościele instytuty życia zakonnego powinny się wzajemnie uzupełniać na polu apostolstwa, a także duchowości. Jan Paweł II nauczał, że wielkim wyzwaniem, jakie czeka nas w trzecim tysiącleciu, jest „,czynić Kościól domem i szkołą komunii” ${ }^{18}$. Do tego programu „duchowości komunii” nawiązał Franciszek w Liście na rozpoczęcie Roku Życia Konsekrowanego, wskazując, że życie konsekrowane ma być świadectwem komunii w obrębie poszczególnych wspólnot zakonnych, a także na zewnątrz nich poprzez wspólpracę z innymi środowiskami kościelnymi i pozakościelnymi ${ }^{19}$. Wskazane jest również to, aby osoby życia konsekrowanego co jakiś czas

16 Por. VC 52.

17 Por. Kongregacja Zakonów i Instytutów Świeckich, „Optiones Evangelicae”. Dokumenty: Zakonnicy i promocja ludzka (12.08.1980), w: Życie konsekrowane $w$ dokumentach Kościola od „Vaticanum” do „Vita consecrata”, red. K. Wójtowicz 1998, nr 24.

18 Jan Pawel II, List apost. Novo millennio ineunte (6.01.2001), $\mathrm{nr} 43$.

19 Por. Franciszek, List apost. do zakonnic i zakonników na rozpoczęcie Roku $\dot{Z} y$ cia Konsekrowanego Świadkowie radości, 21.11. 2014, nr II, 3. 
zwoływały się na wzajemne spotkania, ponieważ bliższa łączność pomiędzy różnymi zakonami wzmocni ich prace apostolskie i przyczyni się do większej jedności.

Wielkim znakiem komunii danej w Kościele jest też jedność wspólnot zakonnych z Kościołem, która przejawia się poprzez łączność z biskupem Rzymu oraz biskupami diecezjalnymi ${ }^{20}$. Zarówno nauczanie II Soboru Watykańskiego, jak i wiele innych dokumentów Kościoła katolickiego popierają więź i harmonię osób konsekrowanych z papieżem ze względu na dobro wszystkich, jakim jest jedność w duszpasterstwie $^{21}$. Więź, jaka istnieje pomiędzy instytutami życia zakonnego a Stolicą Apostolską, jest aspektem powszechności i komunii w Kościele. Ta ścisła relacja zakonów z urzędem papieża i jego misją, niejako ich bezpośrednia zależność od następcy św. Piotra, sprawia, że osoby konsekrowane mogą rozwijać współprace pomiędzy różnymi Kościołami partykularnymi, a także przyczyniać się do inkulturacji Ewangelii Jezusa Chrystusa. Wzrost powołań do życia konsekrowanego w dzisiejszym świecie jest dowodem na to, iż życie oddane na wyłączną służbę Bogu w jedności z Kościołem przyczynia się również do zjednoczenia różnych narodów i kultur ${ }^{22}$. Poprzez ewangelizację misyjną osoby konsekrowane, wypełniając misję życia radami ewangelicznymi oraz zakładając nowe Kościoły lokalne, dążą do zjednoczenia uczniów Chrystusa ${ }^{23}$.

II Sobór Watykański zachęca osoby konsekrowane, aby brały też czynny udział w tak ważnym dziele na rzecz jedności chrześcijan, jakim jest ekumenizm ${ }^{24}$. Osoba poświęcona Bogu w pierwszym rzędzie powinna doświadczyć procesu umierania wraz z Chrystusem, ,,aby wszyscy stanowili jedno" (J 17, ) ${ }^{25}$. Niezgoda i wszelki podział wśród chrześcijan rodzi się z tego, co złe i grzeszne, co jeszcze nie umarło dla Chrystusa. Doświadczenie umierania dla Jezusa nie jest obce osobom konsekrowanym, dlatego też osoby poświęcone Bogu powinny starać się i troszczyć o dzieło ekumeniczne - poprzez wspólną

\footnotetext{
Por. KPK, kan. 590.

21 Por. W. Słomka, Eklezjalny rys życia konsekrowanego, w: ,Vita consecrata”. Adhortacja. Tekst $i$ komentarze, red. A. J. Nowak, Lublin 1999, s. 220-221.

22 Por. VC 47.

23 Por. RM 69. Por. także: Katechizm Kościoła katolickiego, nr 931.

24 Por. Sobór Watykański II, Dekret o przystosowanej odnowie życia zakonnego Perfectae caritatis (28.10.1965) [dalej: PC], nr 2.

21825 Por. A. Warot, „Servitium caritatis”..., dz. cyt., s. 137.
} 
modlitwę, dialog filozoficzno-teologiczny, zaangażowanie - a także o zdrowe wzajemne relacje. Przejawy takie są oznaką powiewu Ducha Świętego, który w swej mocy umacnia, oświeca, a przede wszystkim jednoczy ${ }^{26}$.

Według Jana Pawła II prawdziwa komunia, dialog międzyreligijny będzie owocny wówczas, gdy osoby poświęcone Bogu dadzą prawdziwe świadectwo bycia ubogimi, pokornymi i czystymi. Podobnie też okazywanie serdecznej gościnności, wymiana darów, współpraca, wspólne posługi, to wszystko pozytywnie umacnia podejmowane kroki ekumeniczne.

Tak więc trzeba stwierdzić, że osoby konsekrowane doświadczając jedności w swych wspólnotach zakonnych, które stanowiąjedność z Kościołem, w wielkim stopniu poprzez swoją pracę apostolską przyczyniają się do budowy jedności wśród wszystkich chrześcijan. A cały Kościól jest otwarty na różnego rodzaju poczynania, dzięki którym będzie bardziej zjednoczony ${ }^{27}$.

\section{Troska o miłość braterską we wspólnocie}

Życie braterskie we wspólnocie zakonnej należy rozumieć jako życie wspólne w miłości. Jest to wyraźny znak ukazujący komunię w Kościele. Osoby konsekrowane trwając w miłości braterskiej przyjmują postawę ewangelicznych uczniów, którzy zobowiązali się realizować w swym życiu przykazanie Jezusa Chrystusa: „Przykazanie nowe daję wam, abyście się wzajemnie miłowali tak, jak Ja was umiłowałem" (J 13, 34). Przeogromna miłość Jezusa sprawiła, iż złożył On ofiarę z siebie na krzyżu. Wśród uczniów Jezusowych nie byłoby prawdziwej jedności, gdyby nie było wśród nich bezwarunkowej wzajemnej miłości. Osoby konsekrowane będąc w mocy takiej miłości braterskiej, która rozlana jest w ich sercach za sprawą Ducha Świętego, stają się jednością, mając jednego ducha i jedno serce ${ }^{28}$.

Osoby poświęcone Bogu, żyjące we wspólnocie braterskiej, mają wewnętrzną potrzebę oddania wszystkiego, co posiadają, swej wspólnocie.

26 Por. tamże, s. 138.

27 Por. EV 239.

28 Por. F. Ciardi, Znak wspólnoty - refleksja nad życiem zakonnym, przeł. L. Balter, Poznań 1998, s. 158-161. 
Dzielą się wszystkim, czym dysponują: dobrami materialnymi, swoimi duchowymi doświadczeniami, talentami oraz pomysłami. Współpracują ze sobą w posłudze apostołowania bliźnim oraz szerzenia Bożego miłosierdzia. Duch Święty, obdarzając jedną osobę we wspólnocie swą mocą, udziela jej równocześnie wszystkim członkom wspólnoty, gdyż we wspólnocie moc Ducha Świętego rozprzestrzenia się z jednej osoby na wszystkich ${ }^{29}$.

Życie braterskie we wspólnocie zakonnej odgrywa także ważną rolę w życiu duchowym osób konsekrowanych. W duchowości osób konsekrowanych jest zapisane pielęgnowanie braterstwa. Osoby poświęcone Bogu są zaproszone przez Jezusa Chrystusa do pielęgnowania tegoż braterstwa i jedności w swoich wspólnotach zakonnych ${ }^{30}$. Głęboka troska o życie braterskie osób konsekrowanych jest wyrazem dialogu w łonie Kościoła, a także tworzy klimat akceptacji, który jest przydatny w misji Kościoła ${ }^{31}$.

Trzeba jednak pamiętać, że praktykowanie życia wspólnotowego w miłości braterskiej nie jest czymś łatwym. Wymaga bowiem wysiłku, wielkoduszności oraz ofiar i poświęceń. Dążenie do prawdziwej miłości, do stworzenia pięknej komunii braterskiej często napotyka na różnego rodzaju trudności i przeszkody.

W „,modernizmie” - podkreśla papież Franciszek w encyklice Lumen fidei - starano się budować powszechne braterstwo między ludźmi, przyjmując za podstawę ich równość. Stopniowo jednak rozumieliśmy, że wspomniane braterstwo, pozbawione odniesienia do wspólnego Ojca jako swego ostatecznego fundamentu, nie potrafi się ostać. Trzeba więc powrócić do prawdziwego źródła braterstwa. Od samego początku historia wiary była historią braterstwa, choć nie pozbawioną konfliktów ${ }^{32}$.

Z tego wynika, że jedność braterska musi mieć swoje korzenie w przebaczeniu, a także zdolności przyjęcia i zaakceptowania drugiej osoby taką, jaka ona jest.

Por. VC 45.

30 Por. J. Kałowski, Życie braterskie we wspólnocie, Warszawa 1999, s. 60-61.

31 Por. VC 74. Por. także: A. J. Nowak, Duchowość osób konsekrowanych, w: Vita consecrata. Adhortacja, tekst i komentarze..., s. 186.

32 Franciszek, Enc. Lumen fidei (29.06.2013), nr 54. 
Wspólnota pozwala osobom konsekrowanym poznać trud i radość bycia razem, a także uczy dzielenia się darami dla zbudowania wszystkich. Należy podkreślić również fakt, iż tu, na ziemi, nie było jeszcze doskonałej wspólnoty. Doskonały ideał wspólnoty będzie osiągnięty dopiero w rzeczywistości eschatologicznej ${ }^{33}$.

Papież Jan Paweł II pragnął, aby osoby konsekrowane były mistrzami prawdziwej komunii oraz by żyły tą duchowością, do jakiej zostały powolane w codziennym życiu ${ }^{34}$. Realizacja tego w praktyce oznacza trwanie w miłości bratniej i świadczenie o tym każdego dnia. Dzisiejszy świat domaga się dostrzeżenia radosnych świadków Bożej miłości. Każdy, kto miłuje Boga Ojca, zobowiązany jest także do przelewania tej miłości na wszystkich, w których widzi braci i siostry. Osobie konsekrowanej zanurzonej w Bożej miłości, żyjącej we wspólnocie braterskiej, łatwiej jest otworzyć się na drugiego człowieka i pomóc mu w Jego trudnościach dnia codziennego niż osobie świeckiej. Tylko osoba zintegrowana wokół miłości Bożej przygotowana jest do niesienia pomocy drugiej osobie ${ }^{35}$.

Tak więc miłość braterska wspomaga odnowę życia osób poświęconych Bogu, a także stanowi realizację ich posłannictwa i misji w świecie. Dzisiejszy świat pragnie zobaczyć taką wspólnotę, w której będzie panowała wzajemna miłość, troska o innych, więź braterska, która będzie budzić współodpowiedzialność, przebaczenie, które uleczy wszelkiego rodzaju rany. Wspólnota taka, poprzez swój przykład życia będzie prowadzić wiernych do komunii z Bogiem, a także wniesie wkład w nową ewangelizację, ponieważ będzie pokazywać owoce przykazania miłości, które zostawił nam Jezus Chrystus ${ }^{36}$.

Kościół powierzył wspólnotom zakonnym szczególne zadanie, a mianowicie budowanie komunii, najpierw wewnątrz wspólnot, a potem w otaczającym świecie. Jest to wyjątkowe i zarazem trudne i ważne zadanie, polegające na budowaniu dialogu miłości ze światem. Przykład życia braterskiego ma promieniować szczególnie tam, gdzie są

33 Por. M. Grunt, Mitość w świetle „Vita consecrata”, w: „Vita consecrata”. Adhortacja, tekst $i$ komentarze..., s. 318-319.

34 Por. VC 46.

35 Por. M. Grunt, Mitość w świetle „Vita consecrata”, dz. cyt., s. 319-320.

36 Por. Kongregacja ds. Instytutów Życia Konsekrowanego i Stowarzyszeń Życia Konsekrowanego, Instrukcja Życie braterskie we wspólnocie. „, Congregavit nos in unum Christi amor" (2.04.1994), nr 54-56. 
konflikty etniczne czy też przemoc. Bracia i siostry konsekrowani poprzez wspólne życie stają się wymownym świadectwem dialogu i komunii, która jest w stanie przemienić w harmonię różnego rodzaju nieporozumienia, niesnaski i spory.

Każda wspólnota zakonna jest powołana do tego, aby przez swoje życie w braterstwie ukazać światu wartości chrześcijańskie oraz przemieniającą moc Dobrej Nowiny. Taka wspólnota braterska skłania do patrzenia na ludzi jako dzieci Boże, a także nakłania do ofiarnej miłości. W dzisiejszych czasach międzynarodowe wspólnoty zakonne powołane są do tego, aby zacierać różnice kultur, ras i podtrzymywać komunię między ludźmi. Nie jest to zadanie proste, gdyż wymaga umiejętności twórczego sprostania wyzwaniom inkulturacji przy jednoczesnym zachowaniu swojej tożsamości ${ }^{37}$.

Trzeba jednak wyraźnie stwierdzić, że wspólnota miłości braterskiej jest wielkim dobrem, oparciem i pomocą w pracy wewnętrznej, jak też w dziele apostolskim. Mając to na uwadze, osoby konsekrowane powinny przyczyniać się do wzrostu miłości braterskiej, a także strzec jej integralności. Na pierwszym miejscu należy rozwijać wartości duchowe danej wspólnoty, które podtrzymują więź braterską, oraz ducha miłości. Szczególnym spoiwem łączącym życie wspólne jest miłość Boga, która jest wyrażona przez osobę konsekrowaną w aktywnym wypełnianiu woli Bożej rozpoznanej dzięki natchnieniu Ducha Świętego. Drugą siłą jednoczącą osoby poświęcone Bogu jest miłość do bliźniego, która wyraża się w braterskim obcowaniu z drugą osobą oraz służeniu jej pomocą, a to również wypływa z miłości Boga, gdyż nie można kochać Boga, nie kochając drugiego człowieka ${ }^{38}$.

\section{Posługa charytatywna}

Praktykowanie pracy charytatywnej jest integralną częścią życia chrześcijańskiego. Obowiązek świadczenia pomocy charytatywnej pochodzi z nakazu Jezusa (por. Mt 22, 39; Łk 10, 30-37; Łk 6, 27-36). W Chrystusie także Kościół odnajduje źródło służenia

\footnotetext{
Por. VC 51.

38 Por. S. Miecznikowski, Źródła odnowy duchowej, Warszawa 1993, s. 137-138. Por. także: J. Weismayer, Petnia życia. Zarys historii i teologii chrześcijańskiej duchowości, przeł. J. Zychowicz, Kraków 1993, s. 145.
} 
bliźnim. W Kościele jest wiele grup zaangażowanych w dzieło charytatywne ${ }^{39}$. Jedną z nich są osoby konsekrowane, dążące do miłości drogą rad ewangelicznych, żyjących we wspólnotach braterskich ${ }^{40}$. Osoby poświęcone Bogu poprzez swoją profesję zakonną zobowiązują się do formy życia, która jest radykalnym upodobnieniem się do Chrystusa czystego, ubogiego i posłusznego ${ }^{41}$.

Powołanie chrześcijańskie według II Soboru Watykańskiego jest powołaniem do apostolstwa. Rady ewangeliczne w życiu osoby konsekrowanej tym bardziej są wyrazem oddania się na służbę apostolską Bogu i Kościołowi. Ze szczególnego zespolenia osoby konsekrowanej z Bogiem i Kościołem wynika obowiązek pracy adekwatny do osobistego powołania danej osoby w celu zakorzenienia królestwa Bożego na całym świecie ${ }^{42}$.

W tej perspektywie niezwykle ważnym zadaniem jest odpowiednia formacja osób konsekrowanych do posługi charytatywnej. Adresatami tej formacji są osoby konsekrowane bądź też osoby przygotowujące się do wejścia na drogę rad ewangelicznych. Głównym celem w formacji charytatywnej jest zwrócenie uwagi na całkowite poświęcenie się Bogu i służbie ludziom i nasladowanie Jezusa Chrystu$\mathrm{sa}^{43}$. Wyżsi przełożeni zakonni powinni więc - stosując odpowiednie metody pracy - zadbać o stałą formację osób konsekrowanych, podczas której dane osoby powinny być uwrażliwiane na ludzką biedę i cierpienie stosując. Życie zakonne powinno być przepojone duchem apostolskim, natomiast sama działalność apostolska powinna być kształtowana przez ducha zakonnego, danego instytutom życia konsekrowanego ${ }^{44}$.

Podstawową zasadą apostołowania jest miłość bliźniego, która jest zakorzeniona w miłości Boga. Ta miłość bliźniego nie może być oparta jedynie na wspólczuciu czy też sentymentalizmie, ponieważ to sam

39 Por. Benedykt XVI, Enc. Deus caritas est (25.12.2005) [dalej: DCE], nr 31-39.

40 Por. PC 1.

${ }^{41}$ Por. Benedykt XVI, Adh. apost. Verbum Domini (30.09.2010), nr 83. Por. także: W. Przygoda, Postuga charytatywna Kościota w Polsce, Lublin 2004, s. 163.

42 Por. II Sobór Watykański, Konst. dogm. o Kościele Lumen gentium (21.11.1964), nr 4. Por. także: W. Przygoda, Posluga charytatywna Kościola w Polsce, dz. cyt., s. 163.

43 Por. VC 65.

${ }^{44}$ Por. T. Paszkowska, Charyzmatyczność życia konsekrowanego, w: „Vita consecrata". Adhortacja, tekst i komentarze, dz. cyt., s. 326. 
Bóg zaangażował się w miłość człowieka. Miłość do drugiego człowieka musi się wyrażać w konkretnych czynach miłości ${ }^{45}$. W życiu osoby konsekrowanej miłość bliźniego realizowana jest przede wszystkim we wspólnocie braterskiej. Miłość braterska daje fundament do rozwijania apostolstwa miłości w świecie. Miłość ta jest zalążkiem nowej międzyludzkiej solidarności ${ }^{46}$.

Dla osób konsekrowanych istotną częścią apostolstwa miłości jest działalność charytatywna. Do specyficznych form posługi charytatywnej osób poświęconych Bogu należy: prowadzenie szkół, przedszkoli, domów wychowawczych, „Caritas”, opieka nad ludźmi starszymi, chorymi, niepelnosprawnymi, a także pomoc ludziom z marginesu i dzieciom z rodzin dysfunkcyjnych. Jan Paweł II zachęcał osoby poświęcone Bogu, aby brały czynny udział w tej posłudze. Wedlug papieża praca charytatywna jest pomocna w uświęcaniu siebie, a także pogłębia miłość do Boga i bliźniego ${ }^{47}$.

Dzisiejszy świat oczekuje świadectwa i odpowiedzi od osób konsekrowanych ze względu na szerzącą się chęć posiadania rzeczy materialnych. Odpowiedzią na to jest praca charytatywna, pomoc materialna tym, którzy jej potrzebują, a także pomoc cierpiącym i słabym ${ }^{48}$. Posługa charytatywna jest również świadectwem ewangelicznego wyrzeczenia się i umiarkowania osób konsekrowanych. Przyjęcie prostego i skromnego stylu życia, wejście w relacje z osobami cierpiącymi, wysłuchiwanie ich problemów i zagrożeń dnia codziennego, solidarność z najuboższymi, są to zadania moralne, a także wysoko cenione przymioty osób konsekrowanych zajmujących się posługą charytatywną ${ }^{49}$.

Kościół naśladując Jezusa Chrystusa nawołuje do troski o najuboższych. Przyczyn nędzy drugiego człowieka możemy dopatrywać się w globalnej niesprawiedliwości, która polega między innymi na nierównym podziale dóbr tego świata ${ }^{50}$. Oczekujących na pomoc jest bardzo wielu, są to ludzie zwłaszcza uciskani, starcy, chorzy, zepchnięci

45 Por. DCE 16-18. Por. także: Benedykt XVI, Enc. Caritas in veritate (29.06.2009), nr 1-7; W. Przygoda, Postuga charytatywna Kościoła w Polsce, dz. cyt., s. 165.

46 Por. VC 41. Por. także: M. Grunt, Miłość w świetle „Vita consecrata”, dz. cyt., s. 317.

47 Por. Jan Paweł II, Życie konsekrowane w stużbie Kościoła (11.01.1995.

48 Por. VC 89.

49 Por. VC 90.

22450 Por. Jana Paweł II, Enc. Sollicitudo rei socialis (30.12.1987), nr 13-14. 
na margines, są to ludzie często traktowani jako ostatni w społeczeństwie. Niepodważalnym świadectwem miłości do Boga i bliźniego jest opieka nad opuszczonymi, starcami, niepełnosprawnymi, a także ofiarami narkomanii ${ }^{513}$.

Wspólnoty zakonne, jak pokazuje historia, mają ogromny wkład w dzieło humanizacji świata. Jan Paweł II spoglądając na historię zakonów i ich zasługi oraz troskę o drugiego człowieka stwierdza, iż życie konsekrowane jest żywą egzegezą słów Jezusa: „Wszystko, co uczyniliście jednemu z tych braci moich najmniejszych, Mnieście uczynili” (Mt 25, 40).

Osoby konsekrowane poprzez swój wkład w różnorodne dzieła apostolskie realizują zbawczy plan Kościoła. Papież Paweł VI twierdził, iż apostolstwo osób konsekrowanych jest oryginalne i odznacza się swoistą pomysłowością² . Praca charytatywna ubogaca wspólnotę Kościoła i daje świadectwo o zmartwychwstałym i uwielbionym Synu Bożym, Jezusie Chrystusie. Apostolstwo jest budowaniem królestwa Chrystusowego poprzez miłość do drugiego człowieka. Kościół jest o wiele bogatszy, posiadając w swoich strukturach osoby konsekrowane. Praca charytatywna osób konsekrowanych, zwana również apostolstwem miłosierdzia, ma zatem służebny charakter wobec świata i Kościoła ${ }^{52}$.

\section{Podsumowanie}

Z powyższych rozważań wynika wyraźnie, jak wielkim dobrem dla posłannictwa Kościoła we współczesnym świecie jest apostolstwo osób konsekrowanych. Wspólnoty zakonne w nieoceniony sposób włączają się w proces budowania i kształtowania Kościoła powszechnego w świecie, ubogacając go swoimi charyzmatami, działalnością ewangelizacyjną, posługą charytatywną wśród wiernych oraz troską o jedność i wspólnotę braterską. Dzięki swojemu poświęceniu osoby konsekrowane, pracując wśród dzieci, młodzieży, rodzin, osób niepełnosprawnych, upośledzonych, chorych, ubogich, cierpiących oraz ludzi w podeszłym wieku, stanowią ogromną pomoc w życiu Kościoła

51 Por. Pawel VI, Adh. apost. Evangelii nuntiandi (8.12.1975), nr 69.

52 Por. S. T. Zarzycki, Apostolski charakter życia zakonnego, w: „Vita consecrata”. Adhortacja, tekst $i$ komentarze, dz. cyt., s. 385-386. 
i społeczeństwa. Podkreślić należy wielką siłę modlitwy w intencjach Kościoła i świata i duchowe wsparcie plynące ze wspólnot zakonnych. Dzięki apostolstwu osób konsekrowanych zbawcze słowo Ewangelii dociera do wszystkich miejsc i środowisk, jest obecne we wszystkich kręgach społecznych.

Ojciec święty Franciszek w Liście wydanym z okazji Roku Życia Konsekrowanego podkreslił, że:

cechą charakteryzującą życie konsekrowanego jest proroctwo [...]. Prorok otrzymuje od Boga zdolność zgłębiania historii, w której żyje, i interpretowania zdarzeń: jest jak strażnik, który czuwa w nocy i wie, kiedy nadejdzie jutrzenka (por. Iz 21, 11-12). Zna Boga oraz zna mężczyzn i kobiety, swoich braci i siostry. Potrafi rozeznać, a także jasno wskazać zło grzechu i niesprawiedliwości, bo jest wolny, nie musi odpowiadać przed innymi panami, jak tylko przed Bogiem, nie ma żadnych innych interesów niż sprawy Boże. Prorok staje zazwyczaj po stronie biednych i bezradnych, bo wie, że Bóg jest po ich stronie ${ }^{53}$.

Trudno więc wyobrazić sobie Kościół bez osób zakonnych, członków instytutów świeckich, konsekrowanych dziewic i wdów, bez ich modlitwy, ofiary i prowadzonych przez nich dzieł apostolskich: różnorodnych duszpasterstw, sanktuariów, szkół, mediów, posługi kaznodziejskiej, rekolekcyjnej, służby chorym i ubogim. Historia pokazuje jasno i wyraźnie, że w sytuacjach kryzysu w Kościele Duch Święty powoływał do istnienia nowe charyzmaty zakonne, które przyczynialy się wydatnie do odnowy Kościoła w świecie.

ks. Marek Kluz, Postannictwo osób konsekrowanych we wspótczesnym świecie, [w:] Życie konsekrowane znakiem wiarygodności Kościola, red. ks. Andrzej Dudek, ks. Robert Kantor, Kraków 2016, s. 212-226 (Lumen Gentium, 2).

DOI: http://dx.doi.org/10.15633/9788374385725.13

53 Franciszek, List apost. do zakonnic i zakonników na rozpoczęcie Roku Życia Konsekrowanego Świadkowie radości (21.11. 2014), nr II, 2. 